\title{
AGAMA, MODERNITAS DAN MENTALITAS: Implikasi Konsep Qana'ah Hamka Terhadap Kesehatan Mental
}

\author{
Silvia Riskha Fabriar \\ Universitas Islam Negeri (UIN) Walisongo Semarang \\ Email:silviariskhaf@walisongo.ac.id
}

\begin{abstract}
Diterima: 27 Juni 2020 | Direvisi: 26 September 2020 | Disetujui: 22 Oktober 2020
\end{abstract}
\begin{abstract}
Human life increasingly modern along with the times. However, modernity leads them to become unsafe and uncomfortable living life. Peace of life can only be achieved through the right attitude towards the treasures and sparkles of the other world. This attitude is known as qana'ah, which means feeling sufficient and satisfied for what he has. This study aims to describe the study of qana'ah according to Hamka and to determine its implications in mental health. It is a literature study that using descriptive qualitative methods. The results of this study indicate that qana'ah according to Hamka is an attitude that accepts what it is, but still must make the effort. Qana'ah requires the sincerity of the heart in accepting what is owned by accompanied by maximum effort. If someone practices the concept of qana'ah Hamka, then a healthy mental will be formed. The application of qana'ah in daily life can make a person always optimistic, never give up and not greedy in everything. Someone has control in his own life with qana'ah.
\end{abstract}

Keywords: Qana'ah, Hamka, Mental Hygiene, Mental Health

\begin{abstract}
Abstrak
Kehidupan manusia semakin modern seiring dengan kemajuan zaman. Namun, kadangkala kemodernan tersebut membawa mereka menjadi tidak tenteram dan tidak nyaman menjalani hidup. Ketentraman hidup hanya dapat diraih melalui sikap yang tepat terhadap harta dan gemerlap dunia yang lain. Sikap ini dikenal dengan qana'ah, yang berarti merasa berkecukupan dan puas atas apa yang dimilikinya. Penelitian ini bertujuan untuk mendeskripsikan kajian qana'ah menurut Hamka dan untuk mengetahui implikasinya dalam kesehatan mental. Kajian ini merupakan studi kepustakaan dengan menggunakan metode kualitatif yang bersifat deskriptif. Hasil kajian ini menunjukkan bahwa qana'ah menurut Hamka adalah sikap yang menerima apa adanya, tetapi dengan tetap harus melakukan ikhtiar. Qana'ah memerlukan keikhlasan hati dalam menerima apa yang dimiliki dengan disertai usaha yang maksimal. Apabila seseorang mengamalkan konsep qana'ah Hamka, maka akan terbentuk mental yang sehat. Aplikasi qana'ah dalam kehidupan sehari-hari dapat menjadikan seseorang yang selalu optimis, pantang menyerah dan tidak serakah dalam segala hal. Dengan qana'ah seseorang mempunyai kendali dalam kehidupan.
\end{abstract}

Kata Kunci: Qana'ah, Hamka, Kesehatan Mental, Mental yang Sehat 
Implikasi Konsep Qanaah...

\section{Pendahuluan}

Agama merupakan fitrah setiap orang hidup di dunia. Secara kodrati, manusia membutuhkan pegangan untuk hidup, sebab sekuat apapun manusia tidak akan mampu menyelesaikan segala permasalahannya tanpa campur tangan Tuhan. Islam, sebagai agama rahmat untuk seluruh umat manusia, telah memberikan solusi alternatif bagi umatnya terhadap masalah-masalah yang dihadapi. Al Qur'an telah memberikan banyak petunjuk, berbagai macam terapi kejiwaan, serta nasehat bagi kebahagiaan hidup manusia baik hablum min Allah, hablum min annas maupun hablum min al-'alam. Salah satu sikap yang diajarkan dalam Islam adalah qana'ah. Ajaran qana'ah terlihat banyak tidak diterapkan oleh umat Islam. Pemahaman konsep qana'ah pada mayoritas umat banyak yang kurang tepat. Qana'ah diasumsikan sebagai sikap pasrah terhadap apa yang terjadi dan apa yang dimiliki, nerimo ing pandum, tanpa adanya usaha dan kerja keras.

Hamka merupakan salah satu ulama yang berkontribusi dalam bidang tasawuf. Pemikiran tasawuf Hamka cenderung modern. Hamka memandang dunia secara positif dan memaknai qana'ah sesuai konteks kehidupan. Konsep qana'ah menurut Hamka yaitu menerima apa adanya tanpa menafikkan ikhtiar. Menurut Hamka, orang yang qana'ah tidak dikarenakan harta yang dimilikinya tidak cukup untuk hidup, namun orang yang hidup harus beraktivitas, bekerja dan bergerak agar tidak menganggur (Syukur, 1997: 133). Qana'ah merupakan perilaku yang serdas, karena seseorang akan pandai menghayati apa yang menimpa dirinya, menghadapi urusan dunianya dengan tidak tergesa-gesa.

Kehidupan manusia di era modern dengan berbagai kecanggihan teknologi telah membuat manusia terlena dengan kemegahan, kemajuan dan kemudahan-kemudahan yang ditawarkan modernisasi. Banyak orang beranggapan bahwa modernisasi akan membawa kebahagiaan dan kesejahteraan dalam hidup. Orang-orang banyak melupakan bahwa modernisasi yang serba instan, serba memukau menimbulkan sebuah gejala yang disebut dengan the agony of modernization, yaitu azab sengsara karena modernisasi (Hawari, 1997: 3). Modernisasi yang dihadirkan negara telah membuat manusia berlomba-lomba untuk memenuhi keinginannya sehingga pada suatu sisi justru menjadikannya jauh dari nilai-nilai agama dan bahkan mengalami berbagai 
permasalahan, persaingan, konflik kepentingan dan lain sebagainya akibat dunia yang semakin berkembang. (Dwijayanto, 2020).

Persaingan hidup yang kompetitif membuat manusia mudah terganggu kondisi kejiwaannya. Kondisi kejiwaan atau rohani manusia sangat penting dalam kehidupan. fungsi kejiwaan lain seperti pikiran, perasaan, pandangan, dan keyakinan. Ketidakseimbangan fungsi-fungsi-tubuh baik dari jasmani maupun rohani akan membawa dampak buruk apabila tidak segera diatasi seperti akan menjadikan gangguan kejiwaan bahkan juga penyakit mental atau jiwa. Gangguan kejiwaan menunjukkan adanya kesehatan mental yang tidak baik dalam diri seseorang. Hiruk pikuk kehidupan modern saat ini menjadikan manusia kehilangan sisi spiritualitasnya. Manusia lebih banyak berpikir materialistik, melakukan segala cara untuk mendapatkan harta dan kemewahan dunia. Dalam kondisi yang kejiwaan yang tidak baik, seharusnya manusia kembali kepada fitrahnya, mencari Tuhan melalui agamanya. Sebab, kebutuhan psikis manusia akan keimanan dan ketakwaan kepada Allah tidak akan terpenuhi kecuali dengan agama (Jaelani, 2001: 77).

Dengan demikian, masyarakat modern harus menjadi masyarakat yang relijius juga humanis karena sebagai hamba Allah, mereka mempunyai kewajiban untuk berhubungan secara vertikal maupun horizontal. Berdasarkan hal tersebut, permasalahan yang ingin dikaji penulis adalah bagaimana konsep qana'ah Hamka dan implikasinya terhadap kesehatan mental seseorang dalam kehidupan. Penting kiranya untuk mencari formula yang tepat dalam memahami qana'ah melalui konsep yang dibawa Hamka, agar sikap ini betul-betul dipahami oleh masyarakat dan bisa diterapkan dalam menghadapi kompleksitas kehidupan modern ini.

Kajian ini merupakan penelitian kepustakaan (library research) dengan menggunakan pendekatan kualitatif deskriptif. Data dalam kajian ini diambil dari karyakarya Hamka, khususnya yang berkaitan dengan qana'ah, jurnal, dan buku-buku lain yang relevan dengan tema tulisan ini. Kajian terdahulu yang menjadi pijakan dari tulisan ini adalah kajian Novi Maria Ulfah dan Dwi Istiyani (2016: 95-109) mengenai etika dalam kehidupan modern yang ditinjau dari pemikiran sufistik Hamka. Hasil kajian tersebut menunjukkan bahwa tasawuf modern bagi Hamka merupakan implementasi dari sifat qana'ah, ikhlas, siap fakir namun tetap semangat dalam bekerja dengan niat karena Allah. Hamka juga memberikan panduan dalam beretika bagi 
seseorang berdasarkan profesi masing-masing. Kajian tentang konsep qana'ah juga pernah diteliti oleh Irnadia Andriani dan Ihsan Mz (2019: 64-73).

Penelitian ini mengemukakan tentang konsep qana'ah dalam mewujudkan keluarga harmonis perspektif Al-Qur'an. Kajian tersebut membahas tentang qana'ah dalam Al-Qur'an sebagai solusi untuk menyelesaikan permasalahan dalam keluarga yang tidak harmonis, khususnya dalam masalah ekonomi. Konsep qana'ah yang ditawarkan oleh Hamka belum pernah dibahas secara khusus oleh penulis-penulis sebelumnya, maka penulis tertarik untuk mengkajinya kemudian melihat implikasinya terhadap kesehatan mental seseorang. Kajian ini menempatkan qana'ah bukan sebagai sikap yang pasrah tanpa ada usaha apapun, namun sikap menerima dengan tetap disertai ihktiar dalam menegakkan sendi-sendi kehidupan. Sikap qana'ah yang dikonsepsikan Hamka ini mampu mencegah diri dari gangguan kejiwaan dan menumbuhkan sikap yang dapat mewujudkan mental yang sehat, sehingga jiwa akan merasa damai, tentram, dan bahagia dalam menghadapai segala permasalahan hidup.

\section{Kajian Qana'ah dan Hikmahnya}

Menurut bahasa, kata qana'ah dari bahasa Arab qana'a - qana'an, wa qanaa'atan; radhiya yang berarti merasa puas dengan yang diterima, rela atas apa yang menjadi bagiannya (Munawwir, 1997: 1162). Qana'ah menurut Abu' Abdillah bin Khafifah (Al Qusyairy, 1994: 107) adalah meninggalkan keinginan terhadap suatu yang tidak dimiliki atau hilang dan menghilangkan ketergantungan pada apa yang dimiliki. Al Ghazali menuturkan bahwa orang yang mempunyai keinginan lemah dan meninggalkan mencari sesuatu dialah orang yang qani' (orang yang mencukupkan dirinya dengan apa adanya) (Al-Ghazali: 1985: 136).

Qana'ah adalah perasaan puas dengan segala sesuatu yang dimiliki, merasa cukup dan apa adanya. Qana'ah merupakan sifat mulia yang mencerminkan harga diri dan tolok ukur sebagai akhlak yang tinggi (As Sadr, 2003: 9). Sementara As-Sayyid Bakri al-Makki (1995: 25) mengatakan bahwa qana'ah adalah menerima segala sesuatu apa adanya. Dengan demikian, qana'ah merupakan kepuasan jiwa seseorang terhadap apa yang telah diberikan oleh Allah kepadanya.

Qana'ah ini menjadi penting, karena manusia dalam kehidupannya selalu berhadapan dengan berbagai realitas yang menyenangkan atau yang menyedihkan. Jika 
manusia tidak memiliki rasa qana'ah, maka bisa jadi kejiwaannya akan selalu terganggu. Barnawie Umary (1989) memberikan kriteria atau unsur-unsur yang harus ada dalam qana'ah itu ada 6, yaitu:

1. Berusaha sekuat tenaga.

2. Memohon tambahan yang pantas kepada Allah.

3. Ridho menerima apa yang ada.

4. Sabar menerima ketentuan Tuhan.

5. Tawakal kepada Allah.

6. Tipu daya dunia tiada memperdayainya.

Dengan adanya ketentuan tersebut, orang dapat dikatakan mempunyai sifat qana'ah apabila seseorang merasakan cukup dengan apa yang dimiliki, tidak terlalu tamak dan iri hati dengan yang belum bisa dimiliki, apalagi milik orang lain, bukan seseorang yang meminta lebih terus menerus, sebab hal tersebut mengindikasikan masih miskin, meminta dengan kadar kebutuhan dan kemampuannya. Di samping itu qana'ah menuntut sabar atas ketentuan Allah dan tawakal, tidak bermewah-mewahan, karena kemewahan merupakan tipu daya dunia. Tawakal di sini tentu saja dilaksanakan setelah berusaha semaksimal mungkin.

Dasar qana'ah terdapat dalam Al-Qur'an dan Hadits Nabi, antara lain tersurat dalam Al-Qur'an surat An-Nahl ayat 53, yang artinya "Dan apa saja nikmat yang ada pada kamu, Maka dari Allah-lah (datangnya), dan bila kamu ditimpa oleh kemudharatan, Maka hanya kepada-Nya-lah kamu meminta pertolongan”. Demikian juga dalam sebuah Hadits Nabi yang diriwayatkan Thabrani yang artinya, "Qana'ah itu adalah harta yang tak akan hilang dan pura (persimpanan) yang tidak akan lenyap". (Muvid, 2020: 171). Qana'ah juga tersirat dalam sebuah hadits riwayat Bukhori Muslim (Al-Asqalani, 2009) yang artinya, "Kekayaan itu bukanlah banyaknya harta, tetapi kekayaan itu adalah kaya hati." Kekayaan hati yang dimaksud adalah qana'ah itu sendiri.

Qana'ah memiliki pengaruh yang luar biasa terhadap seseorang. orang yang merasa puas dengan apa yang telah dimilikinya sebenarnya akan merasa lebih bahagia dan lebih tenang daripada orang yang selalu merasa kekurangan. Dengan qana'ah, kondisi kejiawaan seseorang lebih siap menghadapi kehidupan di masa yang akan 
datang, lebih giat mempraktekkan amal shaleh, dan senantiasa lebih mudah meraih kebahagiaan.

Qana'ah berfungsi sebagai pengendali dan penyemangat hidup seorang muslim. Qana'ah disebut sebagai pengendali karena seseorang yang mempunyai sifat qana'ah akan selalu berlapang dada, berhati tentram, merasa berkecukupan, bebas dari rasa tamak. Banyak orang yang tampak dari luar hidup berkecukupan bahkan mewah, namun kondisi hatinya dipenuhi rasa tamak dan gelisah. Sebaliknya ada orang terlihat serba kekurangan dalam kehidupannya namun hatinya tenang, damai, bahagia, dan masih mampu mengelurkan sebagian hartanya untuk kepentingan sosial. Sikap qana'ah juga berfungsi sebagai penyemangat atau motivator dalam hidup. Seseorang akan memiliki kekuatan batin yang selalu mendorong untuk menjalani hidup dengan penuh syukur, semangat dan kerja keras dengan tetap bergantung kepada Allah semata.

Secara umum, hikmah dari sikap qana'ah adalah sebagai berikut:

1. Memberikan rasa tentram dan tenang pada jiwa seseorang karena tidak dihantui tasa tamak dan kekurangan terhadap keduniaan.

2. Mendatangkan etos kerja dan giat berusaha untuk memperoleh sesuatu yang pantas untuk didapatkan, karena semua sudah menjadi ketentuan.

3. Optimis, percaya diri dan tidak ragu-ragu dan syak dalam menghadapi hidup.

4. Hidup sederhana dan bersahaja apa adanya.

5. Membawa seorang muslim untuk tawakal dan sabar dalam menghadapi hidup serta mendorong seorang muslim untuk selalu berusaha mendapatkan kebahagiaan hidup yang sebenar-benarnya, yaitu kaya hati bukan kaya harta.

\section{Kesehatan Mental dan Mental yang Sehat}

Kartini Kartono (1989) menyebut kesehatan mental dengan hygiene mental, yang berarti ilmu kesehatan jiwa yang membahas mengenai kehidupan kerohanian yang sehat dengan menempatkan pribadi manusia sebagai kesatuan totalitas psiko-fisik yang kompleks. Kazdin mengartikan kesehatan mental "as a state in which there is... an absensece of disfunction in phsychological, emotional, behavioral, and social spheres" (Notosoedirdjo, 2002: 24). Menurut Abdul Aziz El Qussy (1974: 38), kesehatan mental yaitu keserasian yang sempurna antara berbagai macam fungsi jiwa diserta kemampuan untuk menghadapi permasalahan-permasalahan jiwa yang ringan. 
Frank L.K. dalam Notosoedirdjo (2002) mengemukakan bahwa kesehatan mental adalah orang yang tumbuh terus menerus, berkembang dan matang hidupnya, bertanggung jawab, dan mampu menyesuaikan diri serta berpartisipasi dalam memelihara aturan sosial dan budayanya. Daradjat (1990) juga menyatakan bahwa kesehatan mental adalah terhindarnya seseorang dari gejala-gejala gangguan dan penyakit jiwa, mampu menyesuaikan diri, mampu memanfaatkan segala potensi dan bakat yang ada semaksimal mungkin dan membawa kepada kebahagiaan bersama beserta tercapainya keharmonisan jiwa dalam hidup.

Orang yang kondisi mentalnya sehat mental akan selalu merasa aman, nyaman, dan bahagia dalam kondisi apapun, juga akan mampu mengontrol dan mengendalikan diri sendiri. Mental yang sehat ialah bersatunya jiwa muthmainnah, jiwa radhiyyah, dan jiwa mardhiyyah (Adz-Dzaky, 2002: 457). Dengan demikian, kesehatan mental berarti keadaan jiwa seseorang yang menjadikannya mampu mengatasi permasalahan kehidupan yang sedang dihadapi dan jiwa yang terhindar dari gangguan bahkan penyakit kejiwaan.

Individu yang mempunyai mental yang sehat relatif mendekati integritas jasmaniah-rohaniah yang ideal. Kehidupan psikisnya tenang dan stabil, tidak menyimpan konflik, dan kondisi jasmaninya selalu sehat dan kuat (Kartono, 1989: 7). Sebaliknya, individu yang mentalnya tidak sehat pasti selalu merasa tidak nyaman, penuh keraguan, gelisah, cemas, serta merasa jauh dari Tuhannya. Daradjat (2001) menjelaskan bahwa gangguan kejiwaan terbagi menjadi dua macam yaitu neurosis (gangguan jiwa atau mental yang ringan; individu yang mengalami masih dalam keadaan sadar) dan psikosis (sakit jiwa; individu yang mengalami tidak sadar dan tidak merasakan apa yang dideritanya).

Menurut Kartini Kartono (1989: 5), orang yang mempunyai mental yang sehat ditandai dengan beberapa hal, antara lain:

1. Memiliki kemampuan untuk bertindak secara efisien.

2. Memiliki tujuan hidup yang jelas.

3. Memilii konsep diri yang sehat.

4. Memiliki integritas kejiwaan, baik secara lahir maupun batin.

5. Adanya kesanggupan melaksanakan tugas-tugas dan tanggung jawab sosial 
Zakiah Daradjat menambahkan unsur agama dalam memberikan batasan untuk mental yang sehat, yaitu jiwa seseorang harus berlandaskan keimanan dan ketaqwaan kepada Tuhan yang bertujuan untuk mencapai kebahagiaan hidup di dunia dan akhirat. (Sururin, 2004: 144).

Kesehatan mental yang terganggu mempengaruhi kehidupan seseorang. Gejalagejala yang ditimbulkan oleh gangguan atau penyakit mental dapat dilihat dari pikiran, pemahaman, tingkah laku dan kesehatan jasmani atau raga. Menurut ajaran Islam, ciri orang yang tidak sehat mentalnya adalah orang yang pendendam, iri hati, sombong, suka membanggakan diri sendiri, riya', pemarah, berburuk sangka, berdusta, tamak, pemalas, pelupa, dan lain sebagainya. Kesehatan mental seseorang dipengaruhi oleh faktor internal dan faktor eksternal. Faktor internal itu meliputi faktor fisik dan psikologis yang ada pada diri seseorang, seperti keyakinan, keimanan, sikap dalam menghadapi permasalahan, dan sebaginya. faktor eksternal yang mempengaruhi kesehatan mental meliputi kondisi lingkungan di luar diri seseorang, seperti kondisi lingkungan masyarakat, keadaan ekonomi dan sosial, pendidikan dan sebagainya.

\section{Konsep Qana'ah Menurut Hamka}

Hamka merupakan salah satu ulama yang memberikan perhatiannya kepada dunia sufistik. Pemikiran Hamka tentang tasawuf bahwa tasawuf sebagai obat untuk membersihkan hati, membersihkan budi pekerti dari perbuatan yang tercela, kemudian menghiasi diri dengan perangai yang terpuji (Hamka, 1990: 202). Tasawuf yang dibangun oleh Hamka menitikberatkan kepada kesalihan spiritual juga sosial. Karena menurutnya, penyakit yang paling berbahaya bagi pribadi manusia adalah mempersekutukan Allah, termasuk mendustakan kebenaran ajaran yang dibawa Rasulullah atau mempunyai sifat dengki, dendam, benci, angkuh, dan sombong terhadap segala amal dan tingkah laku sosialnya. Orang beriman hendaknya berusaha membersihkan jiwa dari luar dan dalam, serta tidak mempunyai niat untuk mengotorinya.

Muvid (2019) menyatakan bahwa tasawuf yang dibangun Hamka juga berbasis kepada koridor syariat agama (tashawwuf masyru'). Tasawuf yang dibangun Hamka bersumber murni dari ajaran Islam, yaitu Al Qur'an dan Hadits. Hamka menekankan kepada setiap orang untuk bertasawuf agar berbudi pekerti yang baik sesuai dengan 
karakter Islam yang seimbang. Hamka (1992) menyatakan bahwa budi pekerti jahat adalah penyakit jiwa, penyakit batin, penyakit hati. Penyakit tersebut lebih berbahaya daripada penyakit jasmani atau badan. Seseorang yang terkena penyakit jiwa akan kehilangan makna hidup yang hakiki.

Hamka menyatakan bahwa tasawuf merupakan aktivitas membersihkan jiwa, mendidik dan mempertinggi derajat budi pekerti, menekan kerakusan, dan memerangi nafsu yang melebihi keperluan diri. Hamka menganjurkan membersihkan diri dengan berbagai latihan diri. Beberapa cara bertasawuf disuguhkan oleh Hamka, diantaranya dengan zuhud, taubah, sabar, tawakal, qana'ah, rela, wara', dan sebagainya.

Hamka (1996) memaknai qana'ah dengan menerima cukup dan didalamnya mengandung lima sikap mental, yaitu:

1. Menerima apa yang ada dengan sukarela

2. Memohon rezeki yang pantas dan terus berusaha

3. Bersabar menerima dengan apa yang dimiliki

4. Berserah diri kepada Tuhan.

5. Tidak terlena dengan gemerlap dunia.

Konsep qana'ah Hamka menuntut adanya keikhlasan dan kerelaan hati dalam menerima apa yang telah dikaruniakan Tuhan dengan selalu berusaha secara maksimal. Selain itu, seseorang juga dituntut untuk bersabar apabila usaha yang dilakukan tidak sesuai dengan apa yang diharapkan. Begitupun sebaliknya, apabila usaha yang dilakukan membuahkan hasil yang baik, maka seseorang harus bersyukur kepada Tuhan atas karunia yang telah diberikan tersebut. Orang yang bersikap qana'ah tidak menutup kemungkinan memiliki harta yang banyak, tetapi hal tersebut tidak membuat orang tersebut terlena dengan harta.

Menurut Hamka, seseorang yang memiliki sikap qana'ah akan membatasi keinginan apa yang sudah ada didalam tangannya dan tidak menginginkan apa yang dimiliki orang lain. Namun, pandangannya tidak menafikan bagaimana dapat terus bertahan hidup, mencari penghasilan, harus bekerja keras dan tidak bermalas-malasan. Manusia dikirim ke dunia untuk bekerja, tetapi harus disadari adakalanya kalah dan menang (Al Kumayi, 2004: 129). Dengan demikian, qana'ah mengajarkan umat manusia agar senantiasa bersyukur dengan rezeki yang dikaruniakan Allah, namun tetap 
optimis dan semangat dalam mencari kebutuhan hidup. Qana'ah tidak berarti sikap fatalis; dimana seseorang yang menerima nasib tanpa ada suatu usaha.

Bagi orang yang benar-benar qana'ah, Hamka (1996: 235) menegaskan bahwa orang tersebut akan selalu berada dalam bimbingan Allah, sehingga ia rela menerima apapun yang telah menjadi ketentuan-Nya. Senang atau susah, kaya atau miskin, baginya hanya pandangan orang lain dari luar. Ia sendiri dalam keadaan tenang, merasakan kenikmatan dan kekayaan hati. Pada saat ditimpa kesusahan, ia senang, sebab kesusahan tersebut dapat mengingatkan kelemahan dan kekurangan dirinya dan kekuatan Tuhannya. Ketika diberi karunia yang banyak, ia juga merasa senang, sebab dengan karunia itu menambah rasa syukurnya kepada Tuhan.

Qana'ah dalam pandangan Hamka, selalu menuntut adanya keikhlasan hati dan usaha keras, memerlukan keikhlasan batin dalam menerima segala kenyataan, karena rasa keikhlasan akan menimbulkan ketenteraman hati, sekalipun kenyataan yang dihadapi tidak sesuai dengan harapan. Qana'ah juga berhubungan dengan usaha keras, sebab menurut Hamka (1996: 233) selama hidup, orang wajib bekerja dan berusaha, bekerja dan berusaha tersebut tidak untuk meminta tambahan yang telah ada, melainkan karena kita hidup sehingga kita wajib bekerja dan berusaha. Usaha ini merupakan sarana untuk menuju ke arah hakikat hidup yang tercermin pada tujuannya (Hamka, 1981: 148). Hal tersebut sama dengan qana'ah Hamka yang selalu mengaitkan antara do'a dan usaha maksimal dalam meraih sesuatu yang diinginkan.

Manusia harus bekerja untuk bertahan hidup, bukan karena ia terobsesi mengumpulkan harta yang banyak. Penjelasan Hamka dengan ini sangat sesuai dengan konteks masyarakat modern saat ini. Menurut Hamka, masyarakat sering memahami qana'ah dengan arti yang keliru. Qana'ah dipahami sebagai sikap yang merasa cukup dengan apa yang telah ada dan tidak mementingkan bekerja atau berusaha. Dengan demikian, qana'ah dipahami sebagai sikap pasrah menerima apa adanya oleh mayoritas masyarakat.

Hamka mengharapkan terciptanya individu yang memiliki kepribadian sufi, yaitu individu yang yang memiliki akhlak terpuji. Sufi di sini tidak dimaknai dalam bentuk tasawuf klasik; dimana individu harus hidup dengan mengasingkan diri atau mempraktikkan kesalehan individu kemudian terasing dari masyarakat. Berkaitan dengan kelima sikap yang terkandung dalam qana'ah, yang mencakup dimensi rela, 
sabar, tawakal, berusaha (ikhtiar), dan tidak tertarik oleh tipu daya dunia akan memberikan pengaruh luar biasa terhadap kondisi kesehatan mental seseorang.

Qana'ah mempunyai ikatan erat dengan syukur. Dua sikap ini bagai dua sisi mata uang yang tidak bisa dipisahkan. Qana'ah dan syukur berjalaln beriringan. Qana'ah mewujudkan rasa syukur, begitu juga sebaliknya, syukur membuahkan qana'ah. Syukur dapat dilakukan dengan lisan, hati maupun perbuatan. Ungkapan syukur dengan hati adalah keinginan untuk senantiasa berbuat baik. Berysukur dengan lisan adalah ungkapan rasa terima kasih, dalam bentuk pujian, kepada siapapun. Bersyukur dengan perbuatan adalah menggunakan nikmat yang Allah berikan untuk mentaati segala perintah-Nya dan menjauhi segala larangan-Nya (Akhyar, 1992: 148)..

Nabi Muhammad saw telah mengajarkan kepada umatnya bagaimana seseorang harus bersikap terhadap harta, yaitu dengan bersikap qana'ah (kepuasan dan kerelaan). Sikap qana'ah harus dimiliki oleh siapa saja baik orang kaya maupun miskin. Wujud qana'ah itu dengan merasa cukup dengan karunia Allah, tidak iri dan tidak serakah melihat harta orang lain, tidak menghalalkan segala cara demi mendapatkan harta benda yang melimpah. Dengan demikian, orang merasa puas dan tidak mencari keinginankeinginan melebihi apa yang dibutuhkan serta mencegah orang menuruti hawa nafsu yang selalu tidak pernah puas.

\section{Implikasi Qana'ah Menurut Hamka terhadap Kesehatan Mental}

Kesehatan mental merupakan kondisi kejiwaan seseorang yang membuat dirinya mampu memecahkan permasalahan hidup yang dihadapi dan terhindar dari gangguan kejiwaan yang berdasarkan keimanan dan ketakwaan untuk mencapai kebahagiaan di dunia dan di akhirat. Semua orang hidup di dunia pasti ingin menikmati ketenangan dan kedamaian dalam hidup. Semua orang berusaha mencari ketenangan tersebut, namun tidak semuanya dapat mencapai apa yang dikehendaki.

Manusia dari segala tingkatan, baik orang yang berpangkat ataupun pegawai biasa pasti menemui kesulitan dengan berbagai macam bentuknya, hanya satu hal yang sama dirasakan yaitu ketidaktenangan jiwa. Untuk mendapatkan ketenangan dan kedaiaman hidup, kebahagiaan batin tidak tergantung dari faktor eksternal seperti kondisi ekonomi, sosial, politik, dan budaya. Namun, ketenangan dan kedamaian hidup tergantung dari kondisi internal masing-masing individu yaitu bagaimana cara dan sikap 
yang digunakan untuk menghadapi faktor-faktor eksternal yang melingkupi diri tersebut.

Dengan demikian, hal yang mempengaruhi ketenangan dan kedamaian hidup adalah kesehatan mental. Kesehatan mental menentukan tanggapan seseorang terhadap suatu permasalahan dan kemampuannya untuk menyesuaikan diri. Kesehatan mental juga menentukan orang mempunyai kegairahan hidup atau tidak bersemangat untuk hidup. Orang yang memiliki mental sehat tidak akan mudah putus asa, pesimis, dan apatis, sebab ia dapat mengahadapi semua rintangan hidup dengan tenang. Orang yang memiliki mental sehat akan mudah beradaptasi, berpartisipasi aktif, mampu membawa diri pada setiap perubahan sosial.

Berkaitan dengan kesehatan mental, Allah menjelaskan dalam Al-Qur'an surat At-Tin: 4, yang artinya, "Sesungguhnya Kami telah menciptakan manusia dalam bentuk yang sebaik-baiknya". Ayat tersebut mengandung maksud bahwa manusia dapat mencapai mental yang sehat, karena Allah telah menciptakan manusia dengan bentuk yang sangat baik, yaitu dengan adanya potensi ruhaniah pada setiap manusia. Potensi ruhaniyah ini dapat dikembangkan oleh setiap orang untuk meraih mental yang sehat.

Orang yang jasmani dan rohaninya akan memancar kebahagiaan di mukanya dan sehat inilah yang diinginkan oleh setiap orang. Dengan kata lain Hamka (1996) menjelaskan bahwa kebahagiaan dapat dicapai dengan beberapa faktor. Salah satu faktornya yaitu kesehatan yang terdiri dari kesehatan badan (jasmani) dan kesehatan jiwa (rohani). Apabila keadaan jiwa sehat, maka dengan sendirinya akan memancarkan kesehatan itu pada mata, dari mata memancar cahaya yang terang, muncul dari jiwa yang tidak sakit. Kesehatan badan juga akan membuka pikiran, mencedaskan akal, dan menyebabkan kebersihan jiwa.

Dengan melihat ciri-ciri mental yang sehat, maka konsep qana'ah yang disampaikan oleh Hamka merupakan bagian dari karakteristik untuk membentuk mental yang sehat. Melalui konsep qana'ah sebagaimana dikemukakan Hamka yang terdiri dari lima sikap yang telah tersebut di atas, dimaksudkan bahwa orang yang tertanam sifat qana'ah dapat menjaga keseimbangan jiwanya, dengan selalu mensyukuri dan sabar dengan apa yang telah dikaruniakan Allah dan senantiasa giat bekerja dalam keadaan apapun. Berlatih bersikap qana'ah dimulai dengan meninggalkan sesuatu hal yang 
diinginkan dan tidak bermewah-mewahan, baik dalam masalah pakaian, tempat tinggal, makanan dan aspek lainnya.

Dengan qana'ah yang di dalamnya terdapat lima sikap mental yaitu harus rela, tawakal, sabar, ikhtiar, dan tidak tertarik tipu daya dunia mempunyai fungsi sebagai pengobatan, pencegahan dan pembinaan. Sebagai pengobatan, dengan memahami dan mengamalkan ajaran qana'ah yang didasari pendekatan sufistik, seseorang akan mempunyai cara untuk memperbaiki keadaan hati yang tidak baik keadaannya. Dengan menjalankan sikap qana'ah akan mempengaruhi pola pikir seseorang dalam menghadapi permasalahan hidup, baik kesenangan maupun kegagalan yang diberikan Allah. Semua peristiwa hidup, apabila dihadapi dengan sikap qana'ah maka akan menjadi obat bagi berbagai penyakit jiwa.

Implikasi qana'ah dalam kehidupan sehari dapat berfungsi sebagai pencegahan dan pembinaan hidup individu. Sebagai pencegahan, qana'ah sebagai pengendali dalam menuruti perasaan, ambisi, dan dorongan-dorongan yang mengarah kepada penyimpangan. Keadaan diri yang tidak terkendali berakibat membawa orang kepada kepincangan, ketidakadilan, dan kesengsaraan bagi diri sendiri dan orang lain. Orang yang tidak mampu mengendalikan dirinya merupakan orang yang mengalami gangguan kejiwaan, seperti egois, selalu gelisah, merasa menyesal, dan sebagainya. Namun, orang yang mampu mengendalikan diri adalah orang yang mempunyai kepuasan dan ketenangan jiwa (Jaya, 1994: 125). Mengendalikan jiwa dan menahan hawa nafsu yang dimaksud juga menahan nafsu untuk serakah, berlebihan yang merupakan kebalikan dari sifat qana'ah, yang sifat-sifat itu membawa ketidaktenangan dan penyakit mental.

Sebagai fungsi pembinaan, setiap orang yang bersikap qana'ah maka ia juga bersikap sabar dan syukur, berarti setiap kali itu juga ia mengarahkan dan membina dirinya dengan kepuasan dan ketenangan jiwa. Semakin tinggi sifat sabar dan syukur, maka semakin kuat motif agamanya atas motif hawa nafsunya, dan semakin puas dan tenang jiwanya, serta semakin taat dan dekat jiwanya dengan Allah. Orang yang bersikap qana'ah memiliki kekuatan batin yang kuat sehingga ia mampu memotivasi diri untuk menjadi lebih baik. Di samping itu, dalam diri orang tersebut akan muncul sikap mandiri, yang hanya bergantung kepada Allah.

Konsep Hamka tentang qana'ah ini bersifat dinamis dan progesif sangat relevan sebagai solusi kekeringan spiritual dan kondisi kejiwaan masyarakat modern saat ini. 
Keadaan masyarakat modern cenderung menggunakan tolok ukur kerja keras, usaha dengan giat dan modal yang besar. Namun mereka tidak terbersit usaha untuk tawakal dan qana'ah terhadap hasil akhir, nilai-nilai spiritualnya dikesampingkan, bahkan tanpa berdo'a kepada Allah dalam setiap aktivitasnya. Mereka hanya bersandar pada usaha, modal, dan hal yang telah mereka rencanakan dengan matang. Banyak dari mereka yang mengalami kegagala. Modal yang banyak dikeluarkan hilang, mereka rugi dan usaha yang sudah mereka lakukan sia-sia. Akibatnya, mereka merasa kecewa, gelisah, putus asa, stres, frustasi, bahkan jatuh sakit.

Sikap manusia yang sangat percaya diri dengan meniadakan peran Allah, secara tidak sadar akan membuatnya menjadi manusia yang merugi. Hal tersebut mengindikasikan bahwa Allah Sang Mahakuasa, manusia dalam setiap usaha dan perencanaanya harus tetap menyandarkan peran dan kuasa Allah agar ia mampu bersikap tenang dan berlapangdada menerima apapun ketika hasilnya tidak tercapai sebagaimana yang telah direncanakan.

Berdasarkan hal di atas, implikasi konsep qana'ah Hamka dalam kesehatan mental terlihat sangat jelas. Manusia yang menerima dengan penuh kerelaan, tidak serakah, menganggap cukup apa yang dimiliki sebagai karunia Allah sambil terus menerus berikhtiar dengan maksimal, lambat laun akan membentuk mental manusia menjadi sehat. Sebab, kesehatan dan penyesuaian mental membutuhkan kebiasaan dan/atau belajar mengatasi konflik mental, ketegangan, dan kegagalan yang dihadapi secara efektif dan sehat. Peranan qana'ah menurut Hamka untuk mencegah munculnya gangguan kejiwaan terdapat pada usaha seseorang yang bersikap qana'ah untuk memelihara diri dari sifat iri, dengki, serakah, cinta dunia, sombong, dan lain sebagainya. Seseorang yang terhindar dari perbuatan tercela tersebut diharapkan mampu menjaga diri dari kemungkinan mengalami kesehatan mental yang buruk atau penyakit jiwa atau batin.

\section{Kesimpulan}

Sikap-sikap yang terkandung dalam konsep qana'ah Hamka merupakan unsur utama yang bisa membangun kepribadian seorang muslim. Qana'ah tidak berarti tidak mempunyai semangat untuk bekerja lebih keras demi menambah rezeki, namun qana'ah berarti tetap optimis, berusaha secara maksimal dengan hanya bergantung kepada Allah 
dan mengaharap ridla Allah. Dengan demikian, qana'ah bertujuan agar setiap manusia selalu bersyukur atas rezeki atau apapun yang telah dikaruniakan Allah. Sikap qana'ah dapat membentuk mental yang sehat. Siapapun yang ingin meraih ketenangan jiwa, ketentraman hati, dan kebahagiaan hidup, maka qana'ah adalah pilihannya.

Diantara hikmah dari sikap qana'ah adalah menimbulkan reaksi fisik dan mental, sehingga pengaruh qana'ah tersebut jelas akan mempengaruhi kejiwaan seseorang. Qana'ah sangat dibutuhkan untuk mengatasi sifat dasar manusia yang tidak pernah merasa puas atas apa yang sudah dimiliki. Qana'ah memberikan pengaruh yang luar biasa terhadap usaha seseorang untuk memperoleh kesehatan mentalnya dengan mengendalikan dari keinginan-keinginan yang berlebihan, hasrat yang tanpa batas serta dorongan-dorongan yang salah. Sebab, salah satu indikasi dari kesehatan mental (jiwa) yang utama adalah kemampuan seseorang untuk menghadapi kesulitan hidup, musibah, dan permasalahan lainnya. Dengan ber-qana'ah orang lebih tenteram, berlapang dada, lebih tenang, tidak dihantui oleh perasaan tamak dan dicekam oleh ketakutan akibat tidak memperoleh sesuatu yang diinginkan. Dalam segala hal mampu dihadapi dengan tenang, tidak takut, menjadi lemah atau bahkan putus asa.

Dengan demikian, kesehatan mental dapat diusahakan, digali, dan dicegah juga dilindungi dengan konsep qana'ah. Namun, agar setiap individu bisa menjalankan sikap qana'ah dengan sungguh-sungguh maka individu harus dibimbing tentang manfaat dan pentingnya qana'ah. Atas dasar itu perlu adanya kajian lebih lanjut mengenai qana'ah dengan tinjauan bimbingan konseling Islam untuk membantu seseorang agar mampu konsisten mengamalkan sikap qana'ah sehingga dapat mencapai kesehatan mental yang baik agar bisa hidup secara seimbang dan tenteram.

\section{Referensi}

Ad Dzaky, Hamdani Bakran. (2002). Konseling dan Psikoterapi Islam, Yogyakarta: Pustaka Pelajar

Akhyar, Towil. (1992). The Secret of Sufi,Studi Pintas Mengenai Rahasia Kehidupan Sufi. Semarang: Asy Syifa'

Al Asqalani, Ibnu Hajar. (2009). Fathul Baari: Syarah Kitab Shahih Al Bukhari. Jakarta: Pustaka Azzam

Al Ghazali. (1985). Ihya' Ulumuddin. Jilid VII, terj. Ismail Yakub. Jakarta: Faizan 
Implikasi Konsep Qanaah...

Al Kumayi, Sulaiman. (2004). Kearifan Spiritual dari Hamka ke Aa Gym. Semarang: Pustaka Nuun

Al Makki, As-Sayyid Bakri. (1995). Merambah Jalan Sufi menuju Surga Ilahi, terj. Ahsin Muhammad. Bandung: Sinar Baru Algensindo

Al Qusyairy, Abd Karim Ibn Hawazin. (1994). Risalah Sufi Al-Qusyairi, terj. Ahsin Muhammad. Bandung: Pustaka

Andriani, Irnadia dan Ihsan Mz. (2019). Konsep Qana'ah dalam Mewujudkan Keluarga Harmonis Perspektif Alquran. Nalar: Jurnal Peradaban dan Pemikiran Islam. Vol 3, No 1, DOI: https://doi.org/10.23971/njppi.v3i1.1291

As Sadr, Sayyid Mahdi. (2003). Mengobati Penyakit Hati, Meningkatkan Kwalitas Diri, terj. Ali bin Yahya. Jakarta : Pustaka Zahra

Daradjat, Zakiah. (1990). Kesehatan Mental. Jakarta: Gunung Agung

Dwijayanto Arik \& Yusmicha Ulya Afif (2020). A Religious State (A Study of Hasyim Asyari and Muhammad Iqbal's Thought on the Relation of Religion, State and Nationalism) JUSPI Jurnal Sejarah Peradaban Islam), 3: 2.

El Qussy, Abdul Aziz. (1974). Pokok-Pokok Kesehatan Jiwa/Mental. terj. Zakiah Daradjat. Jakarta: Bulan Bintang

Hamka. (1981). Falsafah Hidup. Jakarta: Pustaka Panjimas

Hamka. (1990). Prinsip dan Kebijaksanan dalam Dakwah Islam. Jakarta: Pustaka Panjimas

Hamka. (1992). Akhlaqul Karimah. Jakarta: Pustaka Panjimas

Hamka. (1996). Tasawuf Modern. Jakarta: Pustaka Panji Mas

Hawari, Dadang. (1997). Al-Qur'an Ilmu Kedokteran Jiwa dan Kesehatan Jiwa. Yogyakarta: Dana Bhakti Primayasa

Jaelani, AF., (2000). Penyucian Jiwa (Tazkiiyah al-Nafs) dan Kesehatan Mental. Jakarta: Amzah

Jaya, Yahya. (1994). Spiritualisasi Islam: dalam Menumbuh-Kembangkan Kepribadian dan Kesehatan Mental. Jakarta: CV. Ruhama

Kartono, Kartini. (1989). Hygiene Mental dan Kesehatan Mental dalam Islam, Bandung: Mandar Maju

Munawwir, Ahmad Warson. (1997). Al Munawwir, Kamus Arab-Indonesia. Surabaya: Pustaka Progresif 
Muvid, Muhamad Basyrul. (2019). Para Sufi Moderat, Melacak Pemikiran dan Gerakan Spiritual Tokoh Sufi Nusantara Hingga Dunia. Yogyakarta: Aswaja Pressindo

Muvid, Muhamad Basyrul. (2020). Tasawuf Kontemporer. Jakarta: Amzah

Notosoedirjo, Moeljono dan Latipun. (2002). Kesehatan Mental: Konsep dan Penerapan. Malang: UMM Press

Sururin. (2004). Ilmu Jiwa Agama. Jakarta: PT. Raja Grafindo Persada

Syukur, Amin. (1997). Zuhud di Abad Modern. Yogyakarta: Pustaka Pelajar

Ulfah, Novi Maria dan dan Dwi Istiyani (2016). Etika Dalam Kehidupan Modern: Studi Pemikiran Sufistik Hamka. Esoterik: Jurnal Akhlak dan Tasawuf. v.2, n.1, mar. doi:http://dx.doi.org/10.21043/esoterik.v2i1.1896.

Umary, Barnawie. (1989). Materi Akhlaq. Solo: Ramadani 